The Digital Object Identifier - DOI: 10.37952/ROI-jbc-01/20-61-3-126

Submitted on March 6, 2020.

\title{
Specific features of biological oxidation processes in helminthiases of horses
}

\author{
(C) Larisa V. Pilip, ${ }^{*^{+}}$Olga V. Byakova, and Maria E. Kazakova
}

Chair of Zoohygiene, Physiology and Biochemistry. Vyatka State Agricultural Academy. Oktyabrsky Prospect, 133. Kirov, 610000. Russia. Phone: +7 (89991) 00-80-78. E-mail: pilip_larisa@mail.ru

\section{${ }^{*}$ Supervising author; ${ }^{+}$Corresponding author}

Keywords: lipid peroxidation, horses, antioxidant activity, parascaridosis, oxyurosis and strongylatosis.

\section{Abstract}

The chemical processes occurring in the animal body under pathological conditions are of interest to researchers. The objective of the research was to study the indicators of lipid peroxidation and antioxidant activity in horses infested with helminthiases and treated with anthelmintic paste with an antioxidant. The study has proved the role of parasitic infestation in accelerating the processes of free radical oxidation, which is manifested by a decrease in the light sum of radicals (36.62-39.21), the maximum luminous intensity (6.136.98) and antioxidant activity (5.65-6.2) at the start of the research. Chronic invasion increases the concentration of under-oxidized products up to 38.59 , and the rate of initiating free radical oxidation - up to 6.95 , the values of antioxidant activity being stably low (5.51-5.91). An important role in the regulation of lipid peroxidation in horses during helminthiases, as well as in the process of deworming, is played by the antioxidants contained in anthelmintic preparations. The antioxidant santohin included as a compound in the «Alezan» preparation suppresses enhanced peroxidation and activates the antioxidant protection of the body, which is reflected in a decrease in the light sum of the radicals to as low as 26.73 , a maximum luminous intensity to -3.76 , and an increase in antioxidant activity - up to 7.16 .

\section{References}

[1] A.V. Antonov. Selected indicators of antioxidant protection system in sport horses trained with various intensity. Agricultural Biology. 2010. No.4. P.59-65. (russian)

[2] A.V. Antonov. Lipid peroxidation and endurance of horses. Ryazan: Ryazan State Agrotechnological University named after P.A Kostychev. 2011. 108p. (russian)

[3] A.V. Antonov. Lipid peroxidation in sport horses at training. Agricultural Biology. 2009. No.2. P.65-69. (russian)

[4] O.V. Byakova, L.V. Pilip. Lipid peroxidation in horses with intestinal nematodosis. Vestnik Veterinarii. 2012. No.4/63. P.28-30. (russian)

[5] O.V. Byakova, L.V. Pilip, S.N. Belozyorov. Immunological estimation of the paste «Alezan» in helminthiases of horses. Siberian Herald of Agricultural Sience. 2008. No.6. P.99-101. (russian)

[6] E.T. Dadambayev, I.Z. Mambetova, V.R. Shim, K.E. Ibrayeva, B.N. Boketova, S.K. Adambayev. Cell systems of antiradical protection in inflammatory process. Vestnik KazNMU. 2014. No.1. P.28-30. (russian)

[7] E.Kh. Daugalieva, K.G. Kurochkina, A.V. Aripkin. Specific features of immunity in helminthiases. Veterinary Medicine. 1996. No.7. P.37. (russian)

[8] D.V. Trifanova, O.V. Byakova, L.V. Pilip. Parasitic diseases in horses. Youth Science 2014: Technologies and Innovations. 2014. P.233-235. (russian)

[9] B. Halliwel, J. Gutteridge. Free Radicals in Biology and Medicine. New York: Oxford University Press. 1999. P.31-36. 